\title{
KEPATUHAN PELAYANAN FARMASI KLINIK DI RUMAH SAKIT DI RSUP DR. WAHIDIN SUDIROHUSODO
}

\section{CLINICAL PHARMACY SERVICE STANDARD COMPLIANCE IN CENTRAL HOSPITAL DR WAHIDIN SUDIROHUSODO}

\author{
Furqan Djamaluddin ${ }^{1}$, Amir Imbaruddin ${ }^{2}$, dan Muttaqin ${ }^{3}$ \\ ${ }^{1}$ Rumah Sakit Umum Pusat Dr. Wahidin Sudirohusodo Makassar \\ email: furqandj@gmail.com \\ ${ }^{2}$ Sekolah Tinggi Ilmu Administrasi Lembaga Administrasi Negara, Makassar \\ email:_aimbaruddin@gmail.com \\ ${ }^{3}$ Sekolah Tinggi Ilmu Administrasi Lembaga Administrasi Negara, Makassar \\ email: muttaqin_lan@yahoo.com
}

\begin{abstract}
Abstrak
Pelayanan farmasi klinik merupakan salah satu pelayanan kesehatan yang berorientasi kepada pasien sehingga perlu dilakukan kesesuaian standar pelayanan farmasi klinik untuk menciptakan pelayanan yang bermutu dan berkualitas. Tujuan penelitian ini dimaksudkan untuk mengetahui bagaimana kepatuhan Pelayanan Farmasi Klinik di RSUP Dr. Wahidin Sudirohusodo sesuai dengan sebelas indikator pelayanan farmasi klinis berdasarkan Peraturan Menteri Kesehatan Nomor 72 Tahun 2016. Metode penelitian menggunakan pendekatakan kualitatif. Pengumpulan data dilakukan di RSUP Dr. Wahidin Sudirohusodo Makassar dengan Teknik wawancara mendalam, observasi, dan dokumentasi. Informan penelitian adalah Kepala Instalasi Farmasi, penanggung jawab Pelayanan Informasi Obat, penanggung jawab Depo, apoteker, dan pasien. Hasil penelitian menemukan bahwa sebelas indikator pelayanan farmasi klinik yaitu pengkajian dan pelayanan Resep, penelusuran riwayat penggunaan obat, rekonsiliasi obat, Pelayanan Informasi Obat (PIO), konseling, visite, Pemantauan Terapi Obat (PTO), Monitoring Efek Samping Obat (MESO), Evaluasi Penggunaan Obat (EPO), dispensing sediaan steril; dan Pemantauan Kadar Obat dalam Darah (PKOD) sudah dilaksanakan dengan baik walaupun masih ada indikator yang belum optimal. Hanya satu indikator yang belum terlaksana yaitu pemantauan kadar obat dalam darah karena terkendala dengan pembiayaan sarana dan prasarana yang cukup mahal. Kepatuhan Pelayanan Farmasi Klinik di RSUP Dr. Wahidin Sudirohusodo Makassar sudah dilakukan cukup baik tetapi masih terdapat beberapa hal yang perlu dibenahi oleh pihak rumah sakit, diantaranya perlu peningkatan SDM, penjadwalan visite yang lebih intens, penganggaran yang memadai untuk pengadaan alat kesehatan dan produk media edukasi.
\end{abstract}

Kata Kunci: Kepatuhan, Pelayanan, Farmasi Klinik, RSUP Dr. Wahidin Sudirohusodo 


\begin{abstract}
Clinical pharmacy service is one of the patient-oriented health services so that it needs to be done in accordance with clinical pharmacy service standards to create quality and quality services. The purpose of this study was intended to find out how compliance with Clinical Pharmacy Services at RSUP Dr. Wahidin Sudirohusodo is in accordance with eleven clinical pharmacy service indicators based on Minister of Health Regulation No. 72 of 2016. The research method uses qualitative approach. Data collection was conducted at Dr. RSUP Wahidin Sudirohusodo Makassar with in-depth interviews, observation and documentation. The research informants were the Head of Pharmacy Installation, the Person in charge of Drug Information Services, the Responsible Department of Depos, Pharmacists, and Patients. The results found that ten indicators of clinical pharmacy services were assessment and prescription services, tracking drug use history, drug reconciliation, drug information services (PIO), counseling, visite, Drug Therapy Monitoring (PTO), Monitoring of Drug Side Effects (MESO), Evaluation Drug use (EPO), dispensing sterile preparations; and Monitoring of Drug Levels in Blood (PKOD) has been carried out well although there are still indicators that are not optimal. Only one indicator that has not yet been implemented is monitoring blood drug levels because it is constrained by the financing offacilities and infrastructure which are quite expensive. Compliance Clinical Pharmacy Services at RSUP Dr. Wahidin Sudirohusodo Makassar has done quite well but there are still a few things that need to be addressed by the hospital, including the need to increase human resources, scheduling more intense visite, adequate budgeting for the procurement of medical devices and educational media products.
\end{abstract}

Keywords: Compliance, Sevice, Clinical Pharmacy, RSUP Dr. Wahidin Sudirohusodo

\section{PENDAHULUAN}

Menurut Undang Undang Republik Indonesia Nomor 44 Tahun 2009 dan Peraturan Menteri Kesehatan Nomor 34 Tahun 2017, rumah sakit adalah institusi pelayanan kesehatan yang menyelenggarakan pelayanan kesehatan perorangan secara paripurna yang menyediakan pelayanan rawat inap, rawat jalan, dan gawat darurat. Adapun menurut Adikoesoesmo (Alamsyah, 2011), rumah sakit merupakan bagian yang integral dari keseluruhan sistem pelayanan kesehatan yang dikembangkan melalui rencana pembangunan kesehatan. Berdasarkan batasan dan defenisi diatas, maka rumah sakit diartikan sebagai organisasi pelayanan kesehatan masyarakat yang terorganisir secara profesional dan berfungsi sebagai pusat layanan kesehatan bagi pasien dan atau masyarakat yang membutuhkan, tempat pendidikan bagi mahasiswa profesi kesehatan dan sarana penelitian tentang kesehatan yang dapat dikembangkan melalui rencana pembangunan kesehatan.

Sebagai pusat pelayanan publik, rumah sakit membutuhkan manajemen pelayanan yang baik untuk menciptakan pelayanan yang paripurna dan berkualitas. Manajemen merupakan seni dan ilmu perencanaan, pengorganisasian, penyusunan, pengarahan dan pengawasan sumber daya manusia untuk mencapai tujuan yang telah ditetapkan (Manullang, 2008). Adapun 
Luthans (Moenir, 2010) menjelaskan bahwa pelayanan sebagai sebuah proses pemenuhan kebutuhan melalui aktivitas orang lain dalam rangka mencapai tujuannya. Berdasarkan pengertian tentang manajemen dan pelayanan yang telah diterangkan sebelumnya, manajemen pelayanan dapat diartikan sebagai suatu proses penerapan ilmu dan seni untuk menyusun dan mengelompokkan rencana, mengimplementasikan, mengkordinasikan, dan menyelesaikan aktivitas-aktivitas pelayanan melalui pengawasan demi tercapainya tujuan-tujuan pelayanan.

Pelayanan kesehatan merupakan salah satu bentuk pelayanan publik yang menjadi kebutuhan dasar masyarakat dimana setiap individu pernah merasakan sakit sehingga secara otomatis akan membutuhkan pelayanan kesehatan untuk menyembuhkan sakitnya. Berdasarkan Undang-Undang Republik Indonesia Nomor 36 Tahun 2009 tentang Kesehatan, pelayanan kesehatan adalah setiap upaya yang diselenggarakan sendiri atau secara bersama-sama dalam suatu organisasi untuk memelihara dan meningkatkan kesehatan, mencegah dan menyembuhkan penyakit serta memulihkan kesehatan perorangan, keluarga, kelompok dan ataupun masyarakat.
Salah satu komponen penting yang ketersediaannya berpengaruh dalam keberhasilan penyelenggaraan upaya pelayanan kesehatan di rumah sakit adalah sistem kefarmasian. Pelayanan kefarmasian merupakan salah satu kegiatan di rumah sakit yang menunjang pelayanan kesehatan yang bermutu. Hal tersebut diperjelas dalam Permenkes Nomor 72 tahun 2016 tentang Standar Pelayanan Kefarmasian di Rumah Sakit yang menyebutkan bahwa pelayanan kefarmasian rumah sakit adalah bagian yang tidak terpisahkan dari sistem pelayanan kesehatan rumah sakit yang berorientasi kepada pelayanan pasien, penyediaan obat yang bermutu, termasuk pelayanan kefarmasian klinik, yang terjangkau bagi semua lapisan masyarakat.

Standar pelayanan kefarmasian di rumah sakit meliputi dua hal penting, yaitu pengelolaan sediaan farmasi, alat kesehatan, dan bahan medis habis pakai, serta pelayanan farmasi klinik (Permenkes No.72 Thn 2016). Dalam pelaksanaannya, kegiatan kefarmasian di rumah sakit terkadang terdapat keluhan tentang kesalahan terapi obat dikarenakan pemberian jenis obat yang tidak sesuai atau alasan lain. Selain itu, terdapat juga permasalahan tingginya biaya belanja obat dikarenakan adanya kesalahan 
peresepan sehingga terjadi pemberian obat yang berkali-kali dan menjadi terkesan boros.

Pemasalahan ini terjadi karena pelayanan farmasi klinik yang belum berjalan dengan baik. Selain itu tuntutan pasien dan masyarakat akan mutu pelayanan kefarmasian mengharuskan adanya perubahan paradigma pelayanan dari paradigma lama yang berorientasi pada produk obat (drug oriented) menjadi paradigma baru yang berorientasi pada pasien (patient oriented) (Novaryatiin $\mathrm{dkk}$, 2018).

Pelayanan farmasi klinik menjadi salah satu pelayanan yang berorientasi dan bersinggungan langsung dengan pasien. Dengan diterapkannya pelayanan farmasi klinik di rumah sakit maka secara tidak langsung pelayanan yang diberikan apoteker kepada pasien akan meningkatkan outcome terapi dan meminimalkan risiko terjadinya efek samping karena obat. Sehingga tujuan dari keselamatan pasien (patient safety) dan kualitas hidup pasien (quality of life) terjamin (Rusli, 2016). Oleh karena itu, perlu dilakukan kesesuaian standar pelayanan farmasi klinik untuk menciptakan pelayanan yang bermutu dan berkualitas.

Terdapat beberapa penelitian terdahulu terkait dengan standar pelayanan kefarmasian, antara lain penelitian oleh
Restriyani (2016) tentang persepsi dokter dan perawat tentang peran apoteker dalam pelayanan farmasi klinik di Rumah Sakit PKU Muhammadiyah Yogyakarta yang mengindikasikan bahwa karakteristik usia, lamanya masa kerja dan interaksi dengan ahli farmasi mempengaruhi persepsi dokter dan perawat dalam pelaksanaan pelayanan farmasi klinis. Penelitian dari Amaranggana (2017) tentang pelayanan informasi obat yang efektif dari beberapa negara untuk meningkatkan pelayanan farmasi klinik memaparkan kondisi pelayanan kefarmasian terutama dalam bidang pelayanan informasi obat di berbagai negara guna memberikan solusi PIO yang efektif untuk diterapkan di Indonesia. Hasil penelitian menunjukkan bahwa baru sekitar 14\% Rumah Sakit yang dimonitoring telah melakukan Pelayanan Informasi Obat (PIO) yang sesuai, 42\% Rumah Sakit yang baru sebagian menerapkan PIO, dan sekitar 44\% Rumah Sakit belum menerapkan PIO sehingga penelitian ini perlu ditindaklanjuti dengan penelitian lebih lanjut tentang pelaksanaan standar pelayanan kefarmasian di rumah sakit secara spesifik.

Rumah Sakit Umum Pusat (RSUP) Dr. Wahidin Sudirohusodo Makassar termasuk rumah sakit yang dikelola pemerintah dan dikategorikan sebagai rumah sakit rujukan regional berdasarkan surat 
keputusan menteri kesehatan Nomor 540/Menkes/1994 sebagai rumah sakit kelas A dan sebagai rumah sakit pendidikan, serta rumah sakit rujukan tertinggi di kawasan Timur Indonesia. Rumah sakit ini memberikan pelayanan kesehatan paripurna, bermutu, dan terjangkau oleh seluruh lapisan masyarakat sekaligus sebagai tempat pendidikan dan pelatihan tenaga kesehatan serta tempat penelitian dan pengembangan dalam meningkatkan derajat kesehatan masyarakat (RSUP Dr. Wahidin Sudirohusodo Makassar, 2019).

Jumlah tenaga kefarmasian di RSUP Dr. Wahidin Sudirohusodo Makassar sebanyak 140 orang yang hanya terdiri dari 44 orang apoteker. Walaupun Permenkes No. 72 Tahun 2016 ini masih terbilang baru dan jumlah SDM apoteker yang masih terbilang minim, RSUP Dr. Wahidin Sudirohusodo Makassar sebagai rumah sakit rujukan tertinggi di Kawasan Timur Indonesia sudah seharusnya telah melaksanakan standar pelayanan farmasi klinik ini dengan baik untuk dapat menciptakan pelayanan yang paripurna dan berkualitas. Standar pelayanan farmasi klinis ini sangat urgen untuk dapat diterapkan untuk menjamin pelayanan yang sebaik baiknya bagi pengguna layanan. Atas dasar hal-hal yang telah diuraikan, maka tujuan dari penelitian ini yaitu untuk mengetahui Kepatuhan Pelayanan Farmasi Klinik di RSUP Dr. Wahidin Sudirohusodo Makassar berdasarkan Peraturan Menteri Kesehatan Nomor 72 Tahun 2016 tentang Standar Pelayanan Kefarmasian di Rumah Sakit.

\section{METODE PENELITIAN}

Metode penelitian yang digunakan dalam penelitian ini bersifat kualitatif dengan pendekatan deskriptif. Penelitian ini dilakukan di RSUP Dr. Wahidin Sudirohusodo Makassar pada bulan JuliAgustus 2019. Pengumpulan data dilakukan dengan wawancara mendalam, observasi, dan dokumentasi. Adapun informan penelitian adalah Kepala Instalasi Farmasi, Penanggung jawab Pelayanan Infromasi Obat, Penanggung jawab Depo Lontara 3, Apoteker, dan Pasien. Teknik analisis data yang digunakan untuk mengolah data kualitatif berupa data observasi dokumentasi dan wawancara adalah analisis interaktif. Teknik analisis interaktif diadopsi dari model analisis interaktif Miles dan Huberman dengan empat tahapan yang harus dilakukan secara interaktif dan berlangsung secara terus menerus sampai tuntas, antara lain: tahap pengumpulan data, reduksi data, penyajian data, dan penarikan kesimpulan/verifikasi. 


\section{HASIL PENELITIAN}

Dalam sistem pelayanan kesehatan, farmasi klinik merupakan penyedia pelayanan kesehatan yang akuntabel dalam terapi obat serta optimal untuk pencegahan dan penyembuhan penyakit. Pelayanan farmasi klinik terbukti efektif dalam menangani terapi pada pasien. Pelayanan tersebut juga efektif untuk mengurangi biaya pelayanan kesehatan dan meningkatkan kualitas pelayanan kesehatan kepada pasien. Hal tersebut terutama dapat diperoleh dengan melakukan pemantauan resep dan terapi obat serta pelaporan efek samping obat yang terjadi. Pelayanan farmasi klinik yang optimal terbukti dapat menurunkan angka kematian di rumah sakit secara signifikan (Rusli, 2016). Adapun yang termasuk dalam pelayanan farmasi klinik menurut Permenkes Nomor 72 Tahun 2016 tentang Standar Pelayanan Kefarmasian di Rumah Sakit meliputi pengkajian dan pelayanan Resep, penelusuran riwayat penggunaan Obat, rekonsiliasi Obat, Pelayanan Informasi Obat (PIO), konseling, visite, Pemantauan Terapi Obat (PTO), Monitoring Efek Samping Obat (MESO), Evaluasi Penggunaan Obat (EPO), dispensing sediaan steril; dan Pemantauan Kadar Obat dalam Darah (PKOD).

Pelayanan yang pertama yaitu pengkajian resep dilakukan untuk menganalisa adanya masalah terkait obat dalam resep. Pengkajian resep dilakukan dengan melihat secara administrasi, farmasetika dan klinis. Kepala Instalasi Farmasi Rumah Sakit mengatakan bahwa:

"Apoteker di rumah sakit ini selalu melaksanakan pengkajian dan pelayanan resep setiap kali menerima resep dari pasien. Baik itu dilaksanakan di depo depo rumah sakit maupun di satelit jalan" (AK, Juli 2019).

Informan lain juga menambahkan bahwa:

"Untuk memastikan kelengkapan resep, ada ceklis telaah resep yang dibuat di ujung resep. Disediakan kolom ceklis sebelum dan setelah resep dilayani" (HB, Agustus 2019).

Bila ditemukan masalah terkait obat atau adanya ketiklengkapan dan ketidakjelasan resep, maka harus dikonsultasikan kepada dokter penulis resep. Sedangkan untuk pelayanan resep, pada setiap tahap alurnya dilakukan pelayanan resep untuk mencegah terjadinya kesalahan pemberian obat.

$$
\text { Indikator pelayanan kedua, }
$$

Penelusuran riwayat penggunaan obat merupakan proses untuk mendapatkan informasi mengenai seluruh obat/sediaan farmasi lain yang pernah dan sedang digunakan. Riwayat pengobatan dapat diperoleh dari wawancara atau data rekam medik/pencatatan penggunaan obat pasien. 
Informan dalam wawancara mengatakan

bahwa:

"Apoteker harus menanyakan kepada pasien riwayat penggunaan obat sebelumnya walaupun riwayat penggunaan obat juga dapat dilihat pada rekam medis pasien. Jadi itu harus dilakukan pada saat pasien datang. Selain itu, riwayat alergi pasien juga tetap ditanyakan walaupun pada saat dokter melakukan assessment itu sudah terkaji, tapi dari pihak farmasi juga tetap harus melakukan pertanyaan itu kepada pasien" (HB, Agustus 2019).

Tidak hanya riwayat obat, tetapi riwayat alergi dan kepatuhan minum obat juga ditanyakan kepada pasien. Seperti pengakuan oleh pasien rawat jalan yang mengatakan bahwa:

"Sebelum saya diberikan obat oleh petugasnya, saya selalu ditanyakan tentang obat yang pernah saya minum sebelumnya dan ada alergiku atau tidak. Dijelaskan juga cara minum obat dan diingatkan untuk minum obat sesuai aturan yang dia katakan” (S, Juli 2019).

Rekonsiliasi obat, pelayanan yang ketiga, merupakan proses membandingkan instruksi pengobatan dengan obat yang telah didapat pasien. Apoteker harus selalu mencatat penggunaan obat (nama, indikasi, dosis, frekuensi, dan rute), riwayat alergi dan efek samping obat pasien. Informan mengatakan bahwa:

"Ada formnya dan wajib dilakukan. Di clinical pathway, setiap pasien baru, pertama masuk di rumah sakit, lalu pindah ke perawatan, dan juga saat pulang, kita harus lakukan rekonsiliasi untuk mencegah terjadinya duplikasi obat dengan adanya interaksi. Jika terjadi perubahan terapi, apoteker wajib melakukan komunikasi kepada pasien" (HB, Agustus 2019).

Selain itu, informan yang lain juga mengatakan bahwa:

"Jika terdapat ketidaksesuaian dokumentasi, resep, atau obat, maka kami melakukan konfirmasi kepada dokter yang menulis resep. Konfirmasi dulu ke dokternya, apa masalahnya? Apakah pasiennya diberikan obat tersebut apa tidak? Kalau bermasalah, kita tindak lanjuti apakah diganti obatnya atau diberikan solusi lain” (JK, Juli 2019).

Pelayanan keempat, Pelayanan Informasi Obat (PIO) merupakan kegiatan penyediaan dan pemberian informasi, rekomendasi obat yang independen, akurat, tidak bias, terkini dan komprehensif yang dilakukan oleh apoteker kepada dokter, apoteker, perawat, profesi kesehatan lainnya serta pasien dan pihak lain di luar rumah sakit. Berdasarkan aturan, ruangan khusus PIO wajib ada di rumah sakit. Informan mengatakan bahwa :

"Terdapat ruangan PIO tersendiri di instalasi farmasi rumah sakit yang telah dilengkapi dengan pustaka dan telepon. Tetapi di ruang perawatan, bergabung dengan farmasi atau satelitnya" (JK, Juli 2019).

Adapun dari hasil observasi yang dilakukan, ditemukan pula berbagai pustaka, 
buletin, dan leaflet yang dibuat oleh pihak rumah sakit secara berkala di ruang PIO rumah sakit. Selain pengadaan ruangan PIO, hal yang menjadi bagian dalam pelayanan PIO yaitu penyuluhan dan pendidikan berkelanjutan bagi tenaga farmasi dan tenaga kesehatan lainnya. Dalam hasil wawancara, informan lainnya mengatakan bahwa :

"Kami biasa melakukan penyuluhan bekerja sama dengan tim PKRS, dan kadang juga di pasien rawat jalannya tetapi tidak berkala. Untuk Pendidikan dan pelatihan, selain kami yang memfasilitasi dari instalasi untuk melakukan pelatihan-pelatihan, ada juga yang diberi tugas belajar untuk melanjutkan jenjang pendidikannya" (HB, Agustus 2019)

Walaupun dilakukan penyuluhan, akan tetapi belum ada informan dari pasien yang peneliti wawancarai yang mengatakan pernah mendapatkan penyuluhan dari pihak apoteker rumah sakit.

Konseling obat merupakan standar pelayanan yaitu suatu aktivitas pemberian nasihat atau saran terkait terapi obat dari apoteker (konselor) kepada pasien dan/atau keluarganya. Walaupun ada kewajiban apoteker harus melakukan konseling pada semua pasien saat menyerahkan obat, informan (HB, Agustus 2019) menyatakan jika terdapat keterbatasan Sumber Daya Manusia (SDM) maka dapat dilakukan seleksi pasien untuk konseling yang lebih detil siapa yang wajib full mendapatkan konseling, dan siapa yang hanya mendapatkan konseling dasar tentang penggunaan obatnya. Akan tetapi konseling wajib dilakukan oleh apoteker terutama untuk obat-obat yang khusus pada pasien khusus seperti pasien pediatrik, geriatrik, dan pasien dengan penurunan fungsi ginjal dan hati

Hasil observasi diketahui bahwa tidak ditemukan ruang konsultasi khusus di setiap depo dan satelit. Ruang konsultasi obat untuk konseling terdapat di dalam ruangan PIO. Walaupun ruang konseling terpusat di ruangan PIO, akan tetapi apoteker senantiasa memberikan konseling langsung setiap pemberian obat kepada pasien.

Visite merupakan kegiatan yang diatur dalam standar pelayanan berupa kunjungan ke pasien rawat inap yang dilakukan apoteker secara mandiri atau bersama tim tenaga kesehatan untuk mengamati kondisi klinis pasien secara langsung dan mengkaji masalah terkait obat. Kepala Instalasi Farmasi mengatakan bahwa: "Apoteker di rumah sakit ini selalu melakukan visite baik secara tim maupun individu” (AK, Juli 2019).

Akan tetapi karena keterbatasan SDM, visite hanya diprioritaskan kepada pasien risiko tinggi. Selain itu menurut informan (SH, September 2019), apoteker 
juga dapat melakukan kunjungan rumah atas permintaan pasien-pasien yang sudah keluar dari rumah sakit berdasarkan program Home Care dari rumah sakit.

Pelayanan selanjutnya, Pemantauan Terapi Obat (PTO) merupakan suatu proses yang mencakup kegiatan untuk memastikan terapi obat yang aman, efektif dan rasional bagi pasien. Informan mengatakan bahwa:

"Apoteker selalu pro aktif dan kritis terhadap penelusuran Evidence Best Medicine untuk memastikan bahwa obat tersebut merupakan obat yang terbaik digunakan kepada pasien sesuai indikasi sehingga tidak terjadi kesalahan" (JK, Juli 2019).

Selain itu, apoteker senantiasa melakukan pemantauan terhadap pasien terkait efek samping dan efektivitas obat. Sehingga jika diperoleh masalah terkait terapi obat yang dilakukan pasien, maka apoteker melakukan rekomendasi kepada penulis resep.

Layanan yang diatur dalam standar pelayanan, Monitoring Efek Samping Obat (MESO) merupakan kegiatan pemantauan setiap respon terhadap obat yang tidak dikehendaki, yang terjadi pada dosis lazim yang digunakan pada manusia untuk tujuan profilaksis, diagnosa, dan terapi. Kepala Instalasi Farmasi Rumah Sakit memastikan bahwa apoteker melakukan kegiatan Monitoring Efek Samping Obat (MESO) karena kegiatan tersebut merupakan kegiatan nasional yang dilaporkan ke BPOM secara berkala.

"Setiap tenaga kesehatan yang menemukan efek samping terkait penggunaan obat itu harus mengisi form yang telah disediakan. Jadi apapun yang dirasakan oleh pasien, harus dilaporkan. Karena terkadang juga bukan efek samping, melainkan efek alergi. Jadi setiap gejala yang dirasakan pasien harus dilaporkan dan nanti tim MESO yang melihat apakah gejala tersebut merupakan alergi atau efek samping yang nantinya akan dilaporkan ke Badan POM" (AK, Agustus 2019).

Jadi tidak hanya apoteker, tetapi semua tenaga kesehatan di rumah sakit berperan untuk melaporkan dan mencatat ke dalam form ketika menemukan efek samping obat pada pasien. Selain itu menurut informan (RA, September 2019), apoteker senantiasa melakukan identifikasi obatobatan dan pasien yang memiliki risiko tinggi mengalami efek samping obat dan juga mendiskusikan serta mendokumentasikan dengan Tim Farmasi dan Terapi apabila ditemukan efek samping yang terjadi karena obat.

Evaluasi Penggunaan Obat (EPO) adalah layanan berupa program evaluasi penggunaan obat yang terstruktur dan berkesinambungan secara kualitatif dan kuantitatif. Informan mengatakan bahwa :

"Evaluasi penggunaan obat dilaksanakan dengan melihat obat-obatan apa yang 
paling sering digunakan di ruang tersebut, atau antibiotik-antibiotik apa yang paling sering digunakan oleh dokterdokter tersebut" (JK, Juli 2019).

Selanjutnya, dalam wawancara diperoleh pula informasi bahwa apoteker senantiasa melakukan penelitian tentang pola penggunaan obat dan membandingkan pola tersebut dari satu periode ke periode berikutnya. Adapun hasil evaluasi-evaluasi yang ditemukan kemudian dilakukan tindak lanjut untuk perbaikan kedepannya.

Terkait layanan dispensing sediaan steril, Kepala Instalasi Farmasi mengatakan bahwa:

"Apoteker melakukan dispensing sediaan steril. Semua kometerapi dan obat steril yang dicampur jadi satu harus menggunakan teknik anti septik" (AK, Juli 2019).

Kepala Instalasi Farmasi juga mengungkapkan bahwa hal ini sudah menjadi tuntutan akreditasi RSUP Dr. Wahidin Sudirohusodo Makassar.

Hasil observasi yang dilakukan, ditemukan bahwa rumah sakit telah menyiapkan ruangan khusus yang telah dilengkapi sarana dan prasarana untuk dilakukan pencampuran obat suntik, penyiapan nutrisi parenteral, dan penanganan sediaan sitostatik. Selain itu, dari hasil observasi terlihat pula setiap petugas dilengkapi APD dan petugas mengemas obat dan sediaan dengan kemasan tertentu sesuai dengan kebutuhan dan SOP. Selanjutnya, limbah hasil dispensing sediaan steril dibuang pada tempat yang telah disediakan sesuai dengan jenis limbahnya.

Layanan Pemantauan Kadar Obat dalam Darah (PKOD) merupakan interpretasi hasil pemeriksaan kadar obat tertentu atas permintaan dari dokter yang merawat karena indeks terapi yang sempit atau atas usulan dari apoteker kepada dokter. Mengenai hal ini, Kepala Instalasi Farmasi mengatakan bahwa:

"Parameter ke sebelas ini belum bisa berjalan karena terkendala dengan alat dan biaya operasional yang mahal" (AK, Juli 2019)

Belum adanya sarana dan prasarana yang tersedia menjadi penghalang parameter PKOD ini dapat berjalan di RSUP Dr. Wahidin Sudirohusodo.

\section{PEMBAHASAN}

Dalam pelaksanaannya, terdapat sebelas indikator dalam pelayanan farmasi klinik yang pelaksanaannya sebisa mungkin dilakukan secara optimal untuk dapat menurunkan angka kematian di rumah sakit secara signifikan.

Layanan Pengkajian dan pelayanan resep dilakukan untuk mencegah terjadinya kesalahan dalam pemberian obat. Pada pelaksanaan pengkajian resep, apoteker harus 
melakukan pengkajian resep sesuai persyaratan administrasi, persyaratan farmasetik, dan persyaratan klinis baik untuk pasien rawat inap maupun rawat jalan. Pengecekan kelengkapan resep selalu dilakukan oleh pihak apoteker sebagai penerima resep. Adapun cara apoteker di RSUP Dr. Wahidin Sudirohusodo Makassar memastikan bahwa resep yang diterima sudah lengkap dan jelas yaitu dengan membuat format resep yang telah dilengkapi dengan kolom telaah resep farmasi di ujung kanan lembar resepnya. Jika terdapat resep yang tidak lengkap, maka resep tersebut tidak boleh diterima oleh pihak apoteker dan harus dikonfirmasikan ke pihak pembuat resep yaitu dokter. Konfirmasi dilakukan secara langsung atau melalui telepon. Ada pun untuk pelayanan resep yang dimulai dari penerimaan, pemeriksaan ketersediaan, penyiapan sediaan farmasi, alat kesehatan, dan bahan medis habis pakai termasuk peracikan obat, pemeriksaan, penyerahan disertai pemberian informasi juga telah dilakukan oleh pihak rumah sakit. Pada setiap tahap alur pelayanan resep dilakukan sebagai upaya pencegahan terjadinya kesalahan pemberian obat (medication error).

Dari kedelapan informan yang diwawancarai oleh peneliti, semua mengatakan bahwa apoteker selalu melakukan pengkajian dan pelayanan resep sebelum dan setelah resep diterima, baik itu dari pihak pasien yang menerima resep langsung dari dokter dan juga sekaligus sebagai pihak memberikan resep, maupun dari pihak apoteker yang menerima resep dari pasien. Walaupun dalam hasil temuan masih terdapat penulisan resep yang tidak jelas terbaca, akan tetapi apoteker selalu melakukan konfirmasi kembali kepada pihak yang menuliskan resep. Jadi dapat dikatakan bahwa RSUP Dr. Wahidin Sudirohusodo Makassar telah melaksanakan pengkajian dan pelayanan resep sesuai dengan standar pelayanan farmasi klinik.

Terkait Layanan Penelusuran Riwayat Penggunaan Obat, Walaupun telah dilakukan assessment oleh dokter, apoteker juga wajib menanyakan riwayat penggunaan obat sebelumnya dan riwayat alergi pasien. Hal ini dilakukan untuk meminimalisir terjadinya kesalahan dalam pemberian obat. Selain menanyakan langsung kepada pasien, riwayat penggunaan obat pasien juga dapat dilihat pada lembar rekam medik pasien atau lembar daftar penggunaan obat pasien yang ada di depo dan satelit rumah sakit. Hal penting lainnya yang harus dilakukan oleh apoteker yaitu menanyakan tentang kepatuhan minum obat setiap pasien untuk mendukung keberhasilan terapi. Terkhusus 
bagi pasien rawat inap, apoteker memberikan wewenang kepada perawat untuk memberikan obat kepada pasiennya. Hal tersebut dilakukan sebagai salah satu cara untuk mengontrol kepatuhan pasien minum obat.

Semua riwayat penggunaan obat, riwayat alergi, dan pemantauan kepatuhan pasien meminum obat didokumentasikan dalam form tersendiri yang dinamakan LPO (Lembar Pemantauan Obat). Berdasarkan hasil wawancara kedelapan informan di atas, maka dapat dikatakan bahwa RSUP Dr. Wahidin Sudirohusodo telah melaksanakan pemantauan riwayat obat kepada pasien sesuai dengan standar pelayanan farmasi klinik.

Rekonsiliasi obat dilakukan untuk mencegah terjadinya kesalahan obat (medication error) seperti obat tidak diberikan, duplikasi obat, kesalahan dosis atau interaksi obat. Kesalahan obat (medication error) rentan terjadi pada pemindahan pasien dari satu rumah sakit ke rumah sakit lain, pemindahan pasien antar ruang perawatan, serta rentan terjadi pula pada pasien yang keluar dari rumah sakit ke layanan kesehatan primer dan sebaliknya. RSUP Dr. Wahidin Sudirohudo Makassar sendiri selalu melakukan rekonsiliasi obat ketika menerima pasien baru. Ada form rekonsiliasi tersendiri dan wajib dilakukan oleh apoteker. Selain itu, untuk menghindari terjadinya duplikasi pengobatan maka pasien yang baru masuk dan membawa obat dari rumahnya akan disimpankan sementara oleh pihak rumah sakit atau dikonsultasikan terlebih dahulu dengan dokter yang merawat pasien tersebut. Apabila terjadi perubahan terapi, maka pihak apoteker harus melakukan komunikasi dengan pasien, keluarga pasien, atau perawat. Berdasarkan hasil wawancara pada kedelapan informan, maka dapat dikatakan bahwa RSUP Dr. Wahidin Sudirohusodo Makassar telah melaksanakan rekonsiliasi obat sesuai dengan standar farmasi klinik yang ada.

Berkenaan dengan Pelayanan Informasi Obat (PIO) Ruangan Pelayanan Informasi Obat (PIO) di RSUP Dr. Wahidin Sudirohusodo Makassar telah dilengkapi buku-buku dan data-data mengenai obat. Sehingga siapa pun yang ingin mengetahui tentang obat, bisa mencari tahu di ruangan PIO tersebut. Selain disediakannya buku dan informasi, pihak farmasi di rumah sakit juga selalu menerbitkan buletin, leaflet, dan poster secara berkala. Walaupun ruangan PIO sudah ada dan telah dilengkapi dengan fasilitas yang memadai, masih banyak pasien dan tenaga kesehatan yang belum memanfaatkan ruangan tersebut dengan baik. Hal ini 
mungkin disebabkan karena adanya ketidaktahuan pasien dan tenaga kesehatan lainnya tentang ruangan PIO tersebut ataupun karena kurangnya sosialisasi dari pihak farmasi.

Penyuluhan oleh pihak apoteker rumah sakit telah dilakukan, akan tetapi dalam pelaksanaan masih belum maksimal dan belum menjangkau semua tenaga kesehatan serta seluruh pasien yang ada di rumah sakit, baik itu pasien rawat inap dan pasien rawat jalan. Hal ini mungkin disebabkan karena intensitas penyuluhan masih kurang sehingga masih banyak pihak pasien yang mengaku belum pernah mendapatkan penyuluhan dari pihak farmasi rumah sakit.

Berdasarkan kedelapan informan yang peneliti wawancarai, dapat kita simpulkan bahwa kegiatan Pelayanan Informasi Obat di RSUP Dr. Wahidin Sudirohusodo Makassar sudah berjalan sesuai dengan standar pelayanan farmasi klinik walaupun dalam pelaksanaan setiap kegiatannya masih ada yang belum optimal.

Tujuan pemberian konseling obat yaitu untuk mengoptimalkan hasil terapi, meminimalkan risiko Reaksi Obat yang Tidak Dikehendaki (ROTD), dan meningkatkan cost-effectiveness yang pada akhirnya meningkatkan keamanan penggunaan obat bagi pasien (patient safety).

Apoteker memberikan konseling terkait terapi obat yang diberikan rumah sakit kepada pasien. Dalam artian bahwa konseling lebih spesifik kepada individu untuk memahamkan kepada setiap pasien yang menerima obat agar mereka menggunakan obat tersebut secara benar. Konseling dilakukan untuk menggali wawasan pasien tentang obat yang dikonsumsinya, hal ini dipastikan agar apoteker selalu berkomunikasi aktif dengan pasien, baik di rawat jalan maupun di rawat inap.

Walaupun RSUP Dr. Wahidin Sudirohusodo tidak memiliki ruang konsultasi khusus di setiap depo dan satelit, kendala dalam konseling terapi obat di rumah sakit jarang ditemukan sebab pihak rumah sakit sudah menyiapkan berbagai fasilitas dan apoteker (konselor) yang terpusat di ruangan PIO yang dapat dikunjungi setiap saat. Konseling untuk pasien rawat jalan maupun rawat inap di semua fasilitas kesehatan dapat dilakukan atas inisitatif apoteker, rujukan dokter, keinginan pasien atau keluarganya. Pemberian konseling yang efektif memerlukan kepercayaan pasien dan/atau keluarga pasien terhadap apoteker. 
Walaupun ada kewajiban apoteker harus melakukan konseling pada semua pasien saat menyerahkan obat, akan tetapi jika terdapat keterbatasan SDM maka dapat dilakukan seleksi pasien untuk konseling yang lebih mendalam.

Berdasarkan kedelapan informan yang diwawancarai oleh peneliti, maka dapat disimpulkan bahwa RSUP Dr. Wahidin Sudirohusodo Makassar telah melakukan layanan konseling kepada pasien sesuai dengan standar pelayanan farmasi klinik yang ada.

Sebelum melakukan kegiatan visite, apoteker harus mempersiapkan diri dengan mengumpulkan informasi mengenai kondisi pasien dan memeriksa terapi obat dari rekam medik atau sumber lain. Standarnya visite dilakukan kepada semua pasien yang masuk di rumah sakit. Akan tetapi jika terdapat keterbatasan SDM yang ada, maka berdasarkan aturan dapat dilakukan seleksi pasien. Seperti halnya yang terjadi di RSUP Dr. Wahidin Sudirohusodo Makassar, karena keterbatasan SDM maka layanan visite diprioritaskan kepada pasien yang masuk dalam kriteria aturan yang telah ditetapkan.

Pelayanan visite yang rutin dilakukan dan adanya pelayanan Home Pharmacy Care membuktikan adanya pelaksanaan visite yang optimal walaupun dengan keterbatasan
SDM. Sehingga berdasarkan kedelapan informan yang telah diwawancarai oleh peneliti, maka dapat kita simpulkan bahwa pelayanan visite di RSUP Dr. Wahidin Sudirohusodo Makassar telah dilaksanakan sesuai dengan standar pelayanan farmasi klinik.

Pada indikator layanan Pemantauan Terapi Obat (PTO), Apoteker dapat melakukan rekomendasi penyelesaian masalah terkait obat kepada dokter jika memungkinkan karena tujuan dari PTO adalah meningkatkan efektivitas terapi dan meminimalkan risiko Reaksi Obat yang Tidak Dikehendaki (ROTD). Apoteker yang melakukan rekomendasi penyelesaian masalah terkait obat melihat riwayat obat yang telah diberikan kepada pasien. dengan melihat apakah terdapat gejala efek samping atau alergi yang dialami pasien selama mengonsumsi obat tersebut.

Sehingga sangat penting bagi para apoteker di rumah sakit untuk selalu memantau terapi obat yang diterapkan kepada pasien. Pihak rumah sakit sendiri telah melakukan pemantauan terapi obat terhadap pasien terkait efek samping dan efektivitas obat sehingga berdasarkan kedelapan informan yang diwawancarai oleh peneliti, maka dapat disimpulkan bahwa RSUP Dr. Wahidin Sudirohusodo Makassar 
telah melaksanakan pemantauan terapi obat yang sesuai dengan standar pelayanan farmasi klinik.

Rumah sakit mendeteksi adanya kejadian reaksi obat yang tidak dikehendaki dengan berdasarkan form yang telah ditetapkan dalam indicator layanan kefarmasian klinis Monitoring Efek Samping Obat (MESO).

Karena kegiatan yang bersifat nasional, maka setiap orang yang berkontak dengan pasien mempunyai peran penting dalam melaporkan efek samping obat sesegera mungkin. Hal ini dilakukan untuk menghindari kemungkinan yang mungkin lebih fatal. Hasil laporan yang ada kemudian akan dilaporkan ke Pusat Monitoring Efek Samping Obat Nasional. Selain melakukan monitoring langsung pada setiap efek samping obat yang mungkin terjadi, pihak apoteker RSUP Dr. Wahidin Sudirohusodo juga mengidentifikasi obat-obatan dan pasien yang memiliki risiko tinggi mengalami efek samping obat untuk mencegah terjadinya efek samping pada pasien yang berisiko tinggi.

Selain dilakukan pencatatan dan pelaporan, jika ditemukan adanya efek samping obat yang terjadi maka pihak apoteker juga mendiskusikan dan mendokumentasikan dengan Tim Farmasi dan Terapi. Terdapat beberapa hal yang perlu diperhatikan dalam pelaksanaan MESO ini, yaitu kerjasama dengan Komite/Tim Farmasi dan Terapi, ruang perawatan, serta formulir MESO yang senantiasa harus tersedia. Jadi berdasarkan kedelapan informan yang peneliti wawancarai, maka kita dapat menyimpulkan bahwa pelaksanaan monitoring efek samping obat di RSUP Dr. Wahidin Sudirohusodo sudah berjalan baik sesuai dengan standar pelayanan farmasi klinik.

Terkait Evaluasi Penggunaan Obat (EPO), Temuan yang didapatkan adalah apoteker di RSUP Dr. Wahidin Sudirohusodo Makassar telah melakukan evaluasi penggunaan obat secara kualitatif dan kuantitatif yang didokumentasikan dalam sebuah form evaluasi penggunaan obat. Selain itu, penelitian tentang pola penggunaan obat di rumah sakit juga dilakukan. Apoteker membandingkan pola tersebut dari satu periode ke periode berikutnya untuk meminimalisir kasus yang sama dan sesegera mungkin dapat ditindaklanjuti. Berdasarkan kelima informan yang peneliti wawancarai, dapat kita simpulkan bahwa kegiatan evaluasi penggunaan obat di RSUP Dr. Wahidin Sudirohusodo Makassar sudah dijalankan sesuai dengan standar pelayanan farmasi klinik. 
Dispensing sediaan steril harus dilakukan di Instalasi Farmasi dengan teknik aseptik untuk menjamin sterilitas dan stabilitas produk dan melindungi petugas dari paparan zat berbahaya serta menghindari terjadinya kesalahan pemberian Obat. Tidak setiap depo dan satelit harus mempunyai ruangan khusus untuk dispensing sediaan steril. Untuk itu dalam pelaksanaannya, pihak RSUP Dr. Wahidin Sudirohusodo Makassar melakukan sentralisasi dispensing sediaan steril dengan membuat ruangan khusus yang telah dilengkapi dengan fasilitas dan alat pelindung diri yang sesuai standar.

Berdasarkan dari kelima informan yang peneliti wawancarai, dapat kita simpulkan bahwa pelaksanaan dispensing sediaan steril berjalan sesuai standar pelayanan farmasi klinik. Pemantauan Kadar Obat dalam Darah (PKOD) belum dapat berjalan dengan baik karena adanya keterbatasan sarana dan prasarana, jika hanya mau mencegah keracunan digoksin atau obat tertentu lainnya dan untuk mengefektifkan kadar obat dalam darah, maka harus diperhatikan dosis terapi, onset, dan durasi obat tersebut.

Berdasarkan kedelapan informan yang peneliti wawancarai, dapat disimpulkan bahwa RSUP Dr. Wahidin Sudirohusodo
Makassar belum dapat melaksanakan pemantauan kadar obat dalam darah sesuai dengan standar pelayanan farmasi klinik.

\section{KESIMPULAN DAN SARAN}

Kepatuhan RSUP Dr. Wahidin Sudirohusodo Makassar dalam menerapkan standar pelayanan farmasi klinik sesuai dengan Peraturan Menteri Kesehatan No.72 Tahun 2016 tentang Standar Pelayanan Kefarmasian di Rumah Sakit sudah dilakukan dengan baik. Dari kesebelas parameter pelayanan farmasi klinik yang ada, RSUP Dr. Wahidin Sudirohusodo Makassar telah melaksanakan sebelas parameter dengan baik walaupun masih ada beberapa parameter yang belum berjalan dengan optimal, diantaranya: masih adanya penulisan resep yang tidak jelas terbaca, pemanfaatan sarana ruangan PIO yang belum maksimal karena ketidaktahuan pasien dan tenaga kesehatan lainnya, tidak adanya ruang konseling khusus, serta pelaksanaan visite yang belum menyeluruh dilakukan karena keterbatasan jumlah SDM dibandingkan dengan jumlah pasien yang ada di RSUP Dr. Wahidin Sudirohusodo Makassar.

Terdapat satu paramater pelayanan farmasi klinik yang belum dilaksanakan oleh pihak RSUP Dr. Wahidin Sudirohusodo 
Makassar, yaitu parameter Pemantauan Kadar Obat dalam Darah (PKOD). Parameter tersebut belum terlaksana karena terkendala dengan biaya peralatan dan pemeliharaan alat yang cukup mahal. Akan tetapi, untuk meminimalisir kesalahan dalam pemberian obat dan mengefektifkan kadar obat dalam darah karena tidak tersedianya alat PKOD, maka pihak rumah sakit khususnya dokter dan apoteker sangat memperhatikan dosis terapi, dan durasi obat ketika memberikan jenis obat tertentu yang membutuhkan fungsi alat tersebut.

Peneliti menemukan bahwa ada beberapa hal yang perlu dibenahi oleh pihak rumah sakit dalam melaksanakan kegiatan pelayanan farmasi klinik yaitu melakukan upaya pemenuhan seluruh kegiatan farmasi klinik sesuai Permenkes Nomor 72 tahun 2016, melakukan percepatan pembuatan eresep untuk mengurangi kesalahan pembacaan resep, menyiapkan SDM yang memadai untuk kegiatan konseling dan visite, melakukan penjadwalan secara periodik pelaksanaan kegiatan visite. Agar semua pasien dapat dilakukan visite, melakukan penganggaran yang memadai untuk pembuatan leaflet atau edaran informasi obat, dan melakukan penganggaran untuk mengadakan peralatan pemantau kadar obat dalam darah.

\section{REFERENSI}

Amaranggana, Larasati. 2017. Pelayanan Informasi Obat yang Efektif dari Beberapa Negara untuk Meningkatkan Pelayanan Farmasi Klinik: Review. Jurnal Farmaka. 15 (1). p 20-28.

Alamsyah, Dedi. 2011. Manajemen Pelayanan Kesehatan. Yogyakarta: NuhaMedika.

Manullang, Marihot. 2008. Dasar-Dasar Manajemen. Yogyakarta: Gadjah Mada University Press.

Moenir, H.A.S. 2010. Manajemen Pelayanan Umum di Indonesia. Jakarta: PT. Bumi Aksara.

Novaryatiin, Susi dkk. 2018. Tingkat Kepuasan Pasien terhadap Pelayanan Kefarmasian di RSUD Dr. Murjani Sampit. Borneo Journal of Pharmacy. 1(1). p 22-6.

Restriyani, Mustika. 2016. Persepsi Dokter Dan Perawat tentang Peran Apoteker Dalam Pelayanan Farmasi Klinik di Rumah Sakit PKU Muhammadiyah Yogyakarta (Skripsi). Yogyakarta: Universitas Muhammadiyah Yogyakarta. 
Furqan Djamaluddin, Amir Imbaruddin, dan Muttaqin/ Jurnal Administrasi Negara, Volume 25 Nomor 3 (2019)/ 176 - 193

Rusli. 2016. Modul Bahan Ajar Cetak Farmasi: Farmasi Rumah Sakit dan Klinik. Jakarta Selatan: Pusat Pendidikan Sumber Daya Manusia
Kesehatan-Kementerian Kesehatan Republik Indonesia. RSUP Dr. Wahidin Sudirohusodo Makassar. Laporan Triwulan I Tahun 2019. 